\title{
History of U.S. Geological Survey Streamgaging on the Souris River in and near Minot, North Dakota, 1903-2016
}

\section{Introduction}

The Souris River (also known as the Mouse River in the United States) originates in the Yellow Grass Marshes north of Weyburn, Saskatchewan, Canada, and flows southeast, crossing the northern boundary of North Dakota west of Sherwood, North Dakota. The Souris River then forms a loop and flows back north, entering Manitoba, Canada near Westhope, N. Dak., eventually flowing into the Assiniboine River near Brandon, Manitoba (fig. 1).

The U.S. Geological Survey (USGS) began collecting streamflow data, in cooperation with the North Dakota State
Water Commission, on the Souris River in and near Minot, N. Dak., in April 1903. The gage was started up to better understand the water resources available in North Dakota. Currently (2016), water availability is still important as well as the flood monitoring and forecasting that has become an important component of this gage. Gage-height and streamflow data for the Souris River in and near Minot have been collected at five different streamgage locations (table 1, fig. 1). This fact sheet describes the history of streamgaging (locations, gage-height data, and streamflow data) and flooding on the Souris River in and near Minot since 1903.

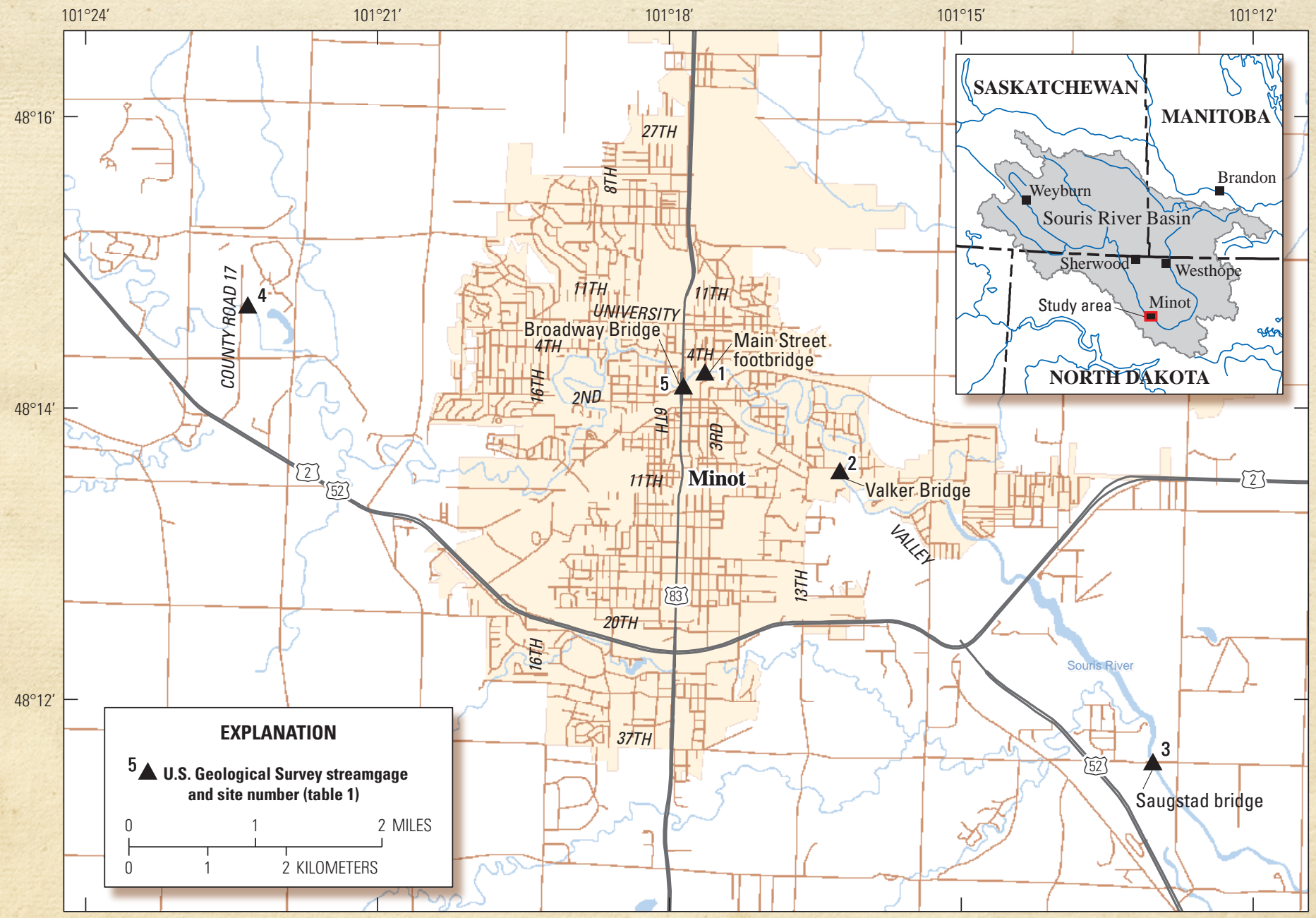

Map image is the intellectual property of Esri and is used herein under license. Copyright (c) 2015 Esri and its licensors. All rights reserved.

Figure 1. Map of the Minot, North Dakota, area with U.S. Geological Survey streamgage locations since 1903. 
Table 1. Selected information for five streamgages monitored in and near Minot, North Dakota.

[NAVD 88, National American Vertical Datum of 1988; N. Dak., North Dakota; USGS, U.S. Geological Survey; current refers to 2016]

\begin{tabular}{|c|c|c|c|c|c|}
\hline $\begin{array}{l}\text { Site number } \\
\text { (fig. 1) }\end{array}$ & $\begin{array}{l}\text { Current streamgage number and } \\
\text { name }\end{array}$ & Period of operation & Historical streamgage name & $\begin{array}{l}\text { Gaging } \\
\text { organization }\end{array}$ & $\begin{array}{l}\text { Gage datum } \\
\text { (feet above } \\
\text { NAVD 88) }\end{array}$ \\
\hline 1 & $\begin{array}{l}05117700 \text { Mouse (Souris) River at } \\
\text { Minot, N. Dak., original site }\end{array}$ & $\begin{array}{l}\text { May 1903-March 1924; } \\
\text { Oct. 1929-Sept. } 1934\end{array}$ & Mouse River at Minot, N. Dak. ${ }^{1}$ & USGS & $1,534.47$ \\
\hline 2 & $\begin{array}{l}05117800 \text { Mouse (Souris) River at } \\
\text { Minot, N. Dak. (Valker Bridge) }\end{array}$ & April 1924-Sept. 1928 & Mouse River at Minot, N. Dak. ${ }^{1}$ & $\begin{array}{l}\text { N. Dak. State } \\
\text { Engineer }\end{array}$ & $1,528.56$ \\
\hline 3 & $\begin{array}{l}05118000 \text { Souris River at Saugstad } \\
\text { Bridge below Minot, N. Dak. }\end{array}$ & Oct. 1928-Sept. 1929 & $\begin{array}{l}\text { Souris River near Minot, } \\
\text { N. Dak. }\end{array}$ & $\begin{array}{l}\text { N. Dak. State } \\
\text { Engineer }\end{array}$ & $1,527.75$ \\
\hline 4 & $\begin{array}{l}05117500 \text { Souris River above Minot, } \\
\text { N. Dak. }\end{array}$ & Oct. 1934-current & Same as current & USGS & $1,547.01$ \\
\hline 5 & $\begin{array}{l}05117600 \text { Souris River at Broadway } \\
\text { Bridge at Minot, N. Dak. }\end{array}$ & March 2011-Oct. 2013 & Same as current & USGS & ${ }^{2} 1.22$ \\
\hline
\end{tabular}

${ }^{1}$ Published as Souris River at Minot, N. Dak., after 1927.

${ }^{2}$ Gage-height record is reported as actual elevation in National Geodetic Vertical Datum of 1929; therefore, a 1.22-foot datum correction is needed for conversion to NAVD 88

\section{Methods Used in Collection of Gage-Height Record}

Methods used in the collection of the gage-height record have changed since data collection began in 1903 for streamgages along the Souris River. Gage-height data collected before October 1934 were obtained by local residents taking water-level observations from a nonrecording staff gage, chain gage, or wire-weight gage (figs. $2 A, 2 B, 2 C$ ), once or twice per day.

Daily gage-height data from October 1934 to June 2016 were obtained from strip chart and digital recording equipment operated by a float sensor housed in a concrete stilling well (fig. 3). The stilling well protects the float and dampens the fluctuations in the stream caused by wind and turbulence and is generally considered the most accurate measure of stream gage height. Strip chart equipment recorded the water level continuously, whereas digital equipment recorded an instantaneous water-level reading in 15- or 60-minute intervals (fig. 4).
The daily gage-height (also known as stage) value, for a given day, is the mean of the 24-hour period recorded for that particular day. The equipment and USGS methodology for the observation, sensing, and recording of gage height in streams is described in Sauer and Turnipseed (2010). Before October 1, 2000 , the mean daily gage-height data for the five streamgages (fig. 1, table 1) on the Souris River in and near Minot were not published, with a few exceptions, even though the mean daily gage height was used in the computation of a daily streamflow value. The available archived mean daily gage-height data for four of the five streamgages with periods of record before October 1, 2000, have been loaded into the USGS National Water Information System (NWIS) database (http://waterdata. usgs.gov/nd/nwis/), on a per site basis, for the available period of record beginning as early as April 1903 through September 30, 2000. The gage-height record for the five locations is available at http://waterdata.usgs.gov/nd/nwis/dv. The streamgage of interest can be selected by using the streamgage numbers provided in table 1 .
$\boldsymbol{A}$

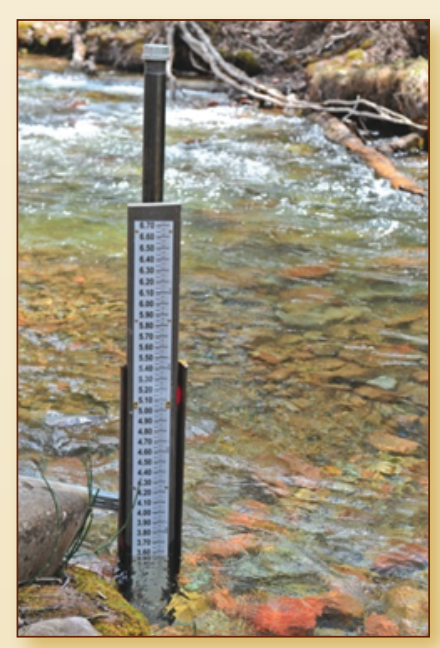

B

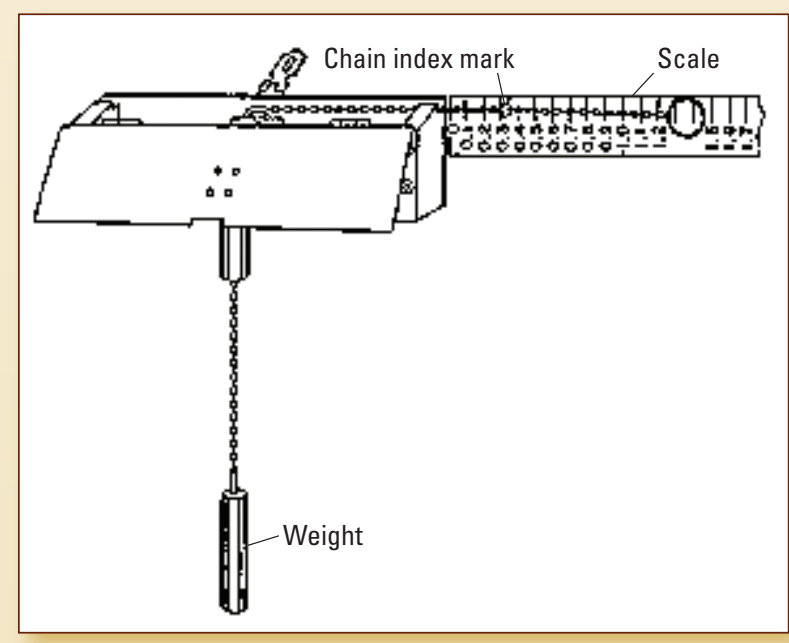

C

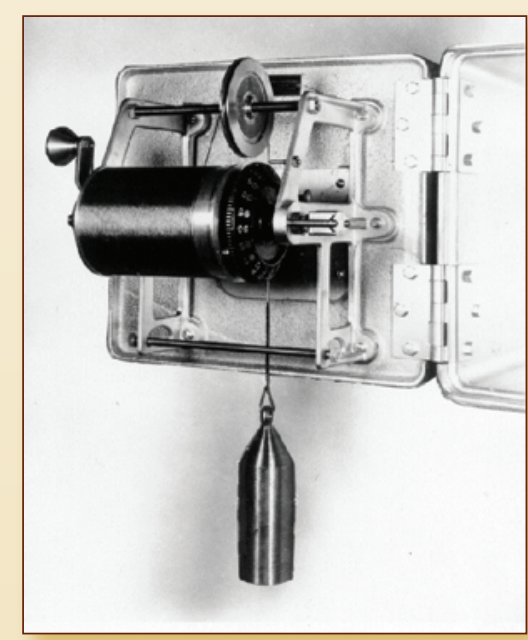

Figure 2. Selected historical methods used for the collection of gage-height data by the U.S. Geological Survey. $A$, staff gage; $B$, chain gage; and $C$, wire-weight gage. 
Figure 3. Schematic showing stilling well installation (from Sauer and Turnipseed, 2010).
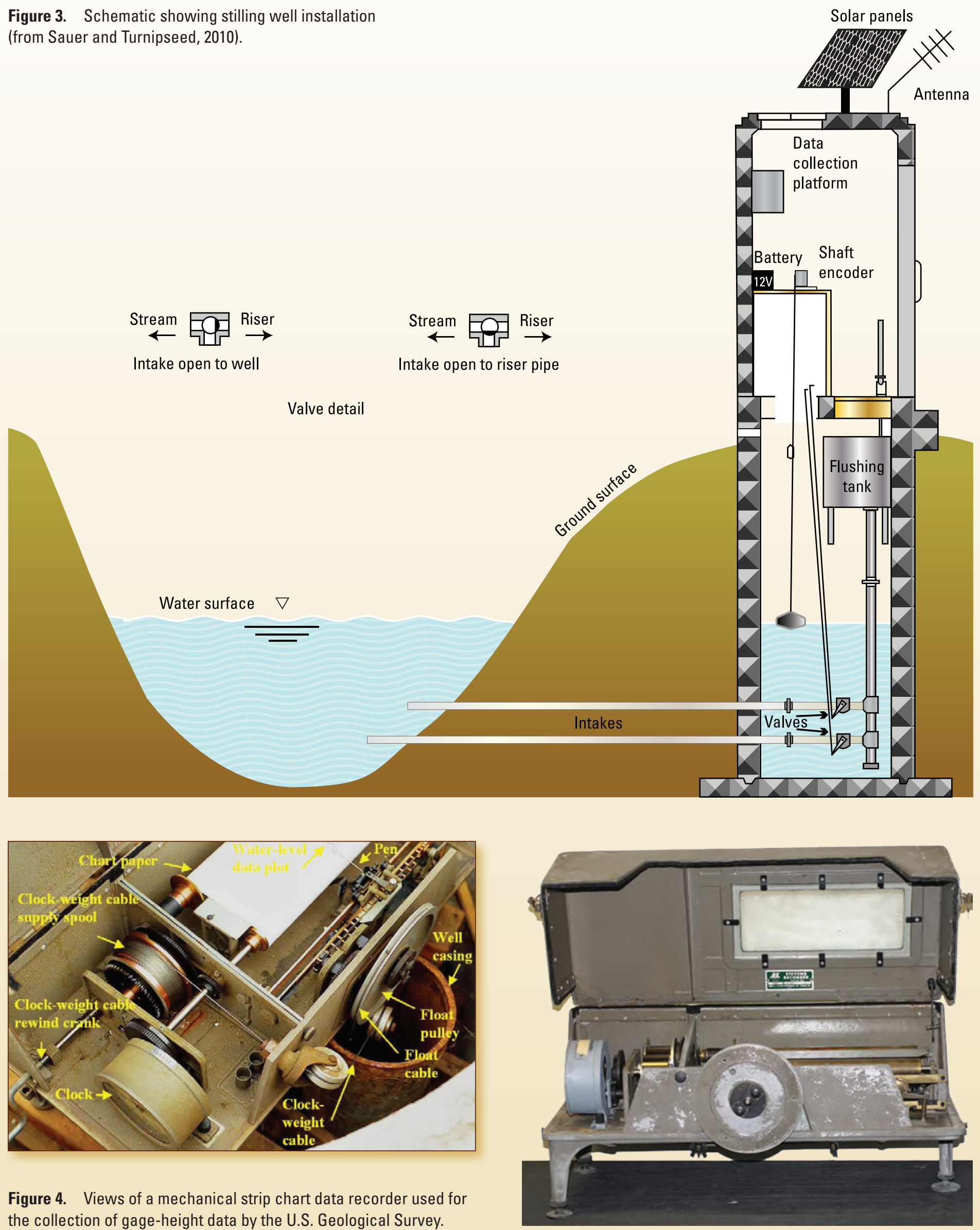

Figure 4. Views of a mechanical strip chart data recorder used for the collection of gage-height data by the U.S. Geological Survey. 


\section{Streamgage Locations on the Souris River in and near Minot, N. Dak.}

The names, physical locations, and gage datums for the five streamgages monitored by the USGS along the Souris River in and near Minot (table 1) have changed through time. The following sections describe these historical changes. To determine the correct elevation of the water surface at a gage, the gage height needs to be added to the gage datum. The gage datum is an arbitrary horizontal surface used as a zero point for measurement of gage height and is selected so the datum is slightly below the lowest point of the stream bottom such that the gage height is usually slightly greater than the maximum depth of water.

\section{Streamgage 05117700 — Mouse (Souris) River at Minot, N. Dak., Original Site (Site 1)}

Streamgage 05117700 was established by the USGS on May 5, 1903, on a footbridge northwest of the Great Northern Railroad roundhouse east of the current (2016) Broadway Bridge (fig. 1). In 1909, the footbridge was removed and replaced with another footbridge at Anne Street (fig. 1; currently [2016] known as the Main Street footbridge) a few hundred feet downstream from the previous bridge. The gage datum did not change between the sites. The streamgage was discontinued by the USGS in March 1924.

In October 1929, the USGS reestablished the streamgage and moved the gage back to the Main Street footbridge. Data collected after 1929 for this streamgage were published as Souris River at Minot, N. Dak. This streamgage was discontinued September 1934.

\section{Streamgage 05117800-Mouse (Souris) River at Minot, N. Dak. (Valker Bridge; Site 2)}

After the USGS discontinued streamgage operation at site 1 in April 1924, the North Dakota State Engineer maintained a gaging history for the Souris River at Minot from April 1924 through September 1928 at streamgage 05117800. This streamgage was established at the Valker Bridge (currently [2016] 8th Avenue Southeast) in the southeast part of Minot (site 2, fig. 1). The streamgage maintained the same name (Mouse River at Minot, N. Dak.) but with a different datum than used at site 1 on the Main Street footbridge. Streamflow records for the site 2 streamgage were obtained from the Biennial Reports of the State Engineer to the Governor of North Dakota (North Dakota State Water Commission, 1927-28).

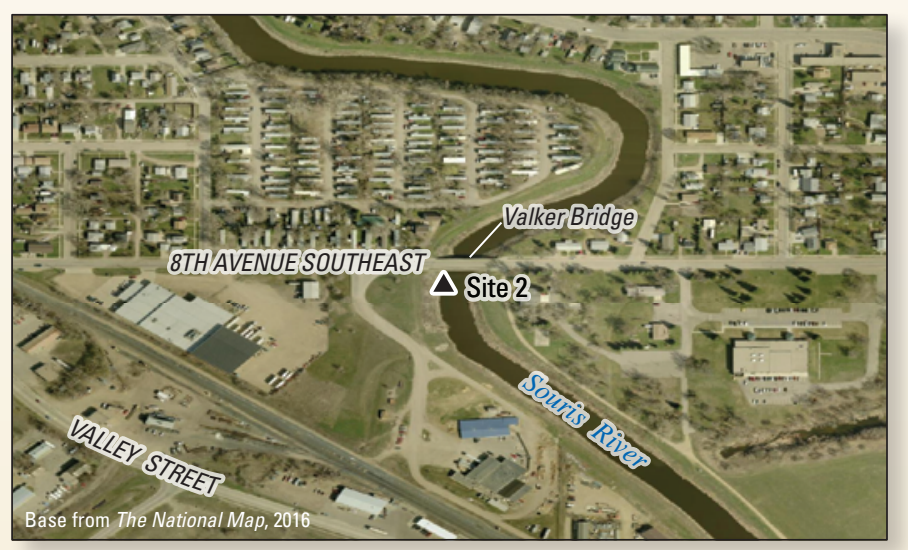

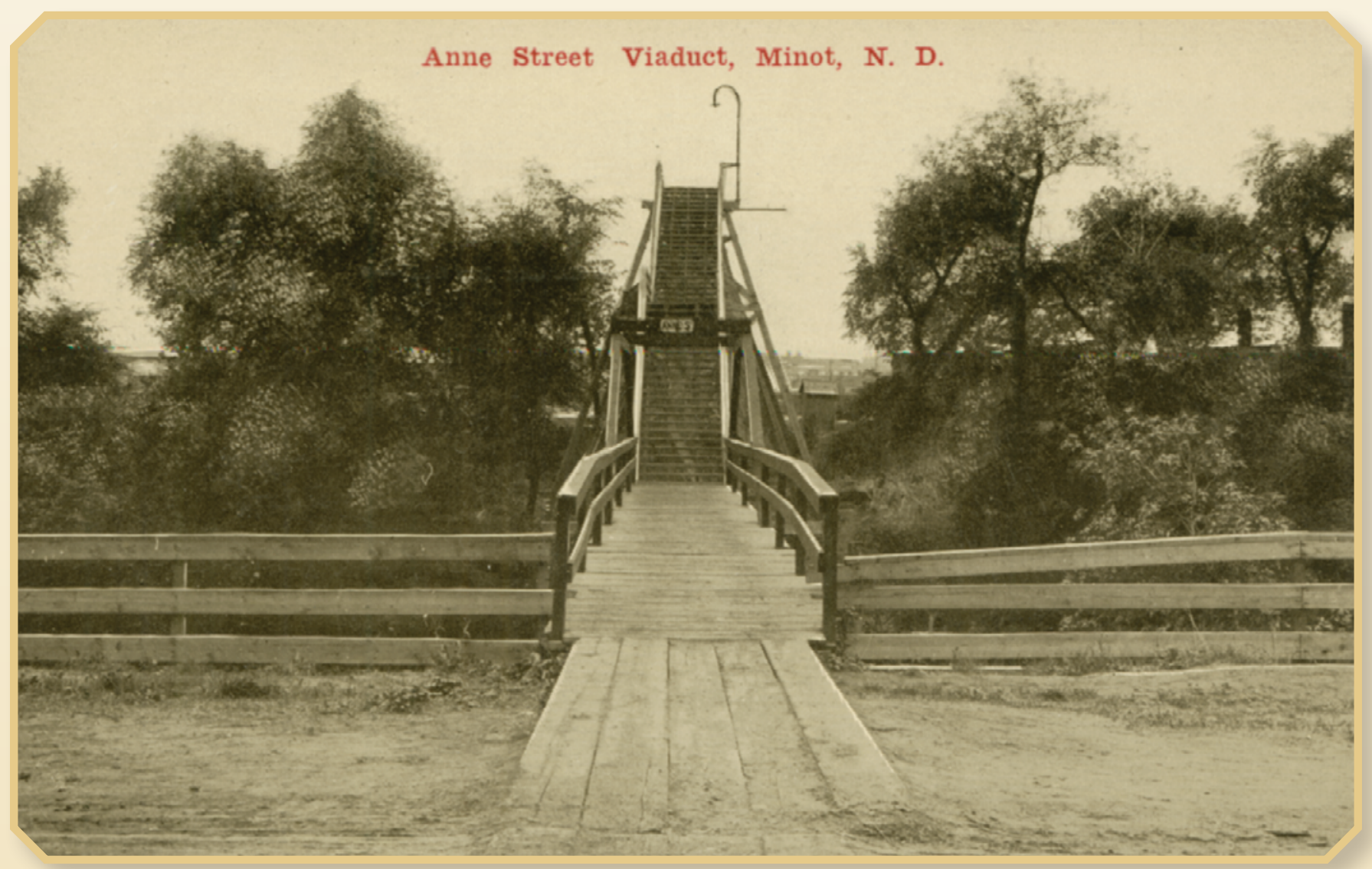

Figure 5. Photograph of the Anne Street viaduct taken sometime between 1900 and 1915. (Photograph courtesy of the State Historical Society of North Dakota, file identification number B0756-80.) 


\section{Streamgage 05118000—Souris River at Saugstad Bridge below Minot, N. Dak. (Site 3)}

The North Dakota State Engineer operated a gage at Saugstad Bridge from October 1928 through September 1929 (North Dakota State Water Commission, 1929-30). Data for streamgage 05118000 were published under the name Souris River near Minot, N. Dak. Site 3 was 5 miles southeast of Minot on the Saugstad Bridge (currently [2016] 37th Avenue Southeast) with a different datum than the two previously described streamgages (sites 1 and 2, fig. 1).

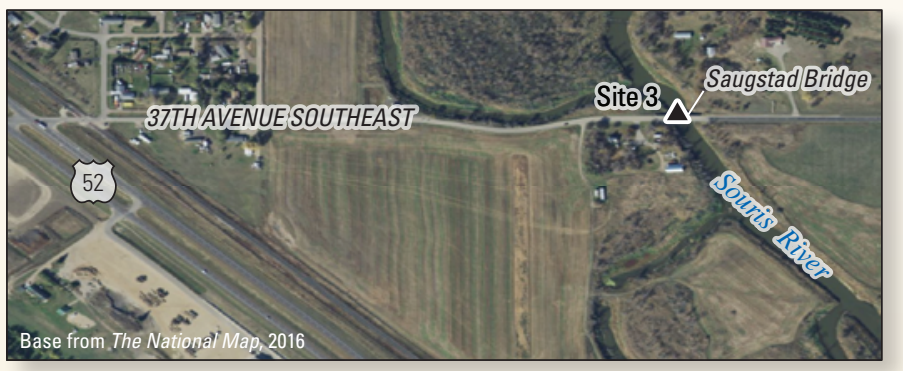

\section{Streamgage 05117500—Souris River above Minot, N. Dak. (Site 4)}

The USGS established a stilling well type gage (fig. 3) with continuous recording equipment about 3.5 miles west of Minot downstream from the bridge on County Road 17 in October 1934 (site 4, fig. 1). Data collected at streamgage 05117500 have been published as Souris River above Minot, N. Dak., and the streamgage has been in continuous use to present day (2016).

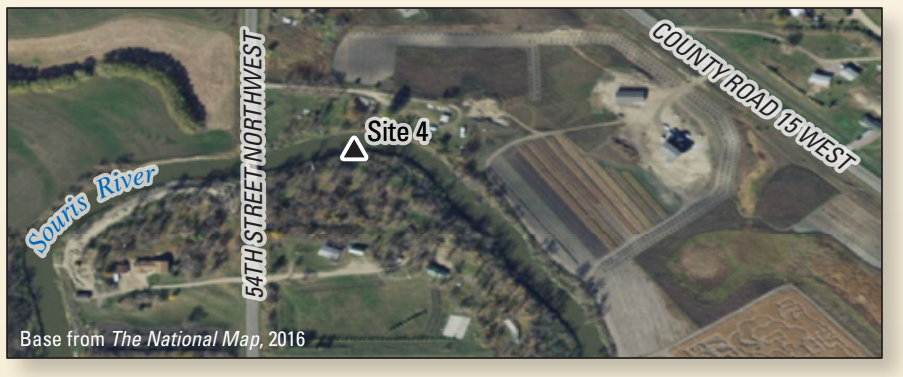

\section{Streamgage 05117600 — Souris River at Broadway Bridge at Minot, N. Dak. (Site 5)}

The USGS installed streamgage 05117600 at the Broadway Bridge in March 2011 (site 5, fig. 1). This gage was a temporary addition to the continuous gaging network during the record flooding of 2011. Site 5 was a miscellaneous wire-weight gage (fig. 2C) with recording equipment installed that was operated from March 2011 through October 2013. Daily gage-height record before April 2016 was originally published under streamgage 481417101174500 . The 15 -digit streamgage number was revised to the current (2016) 8-digit streamgage number in April 2016.

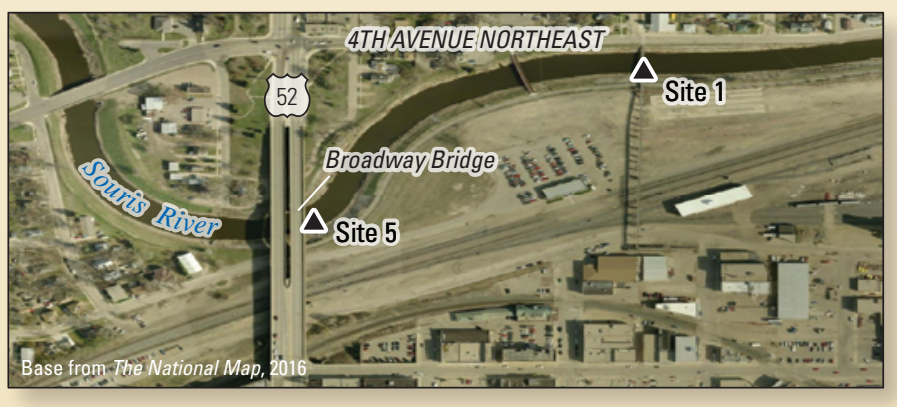

\section{Discharge Measurements}

From April 1903 through September 1934, all USGS discharge (streamflow) measurements were made directly in Minot, typically from one of the bridges in town, or wading near the then active streamgage (site 1 or 2). Before 2016, these discharge measurements were not available in the USGS NWIS database. In the spring of 2016, all discharge measurements made April 1903 through September 1934 were loaded into the USGS NWIS database. These discharge measurements are now stored and available under streamgage 05117700 .

From October 1934 to present (2016), all USGS discharge measurements have been made near site 4 , which is upstream of Minot, and are stored in the USGS NWIS database under streamgage 05117500 .

The USGS made 16 discharge measurements from the Souris River at Broadway Bridge at Minot, N. Dak. (site 5, fig. 1) during May 2011-13. These discharge measurements are stored under streamgage 05117600 in the USGS NWIS database (http://waterdata.usgs.gov/nd/nwis/).

\section{Daily Discharge Records}

The daily discharge records (also known as the streamflow records) were collected at the streamgages for the period of operation noted in table 1 . After the early streamgages (sites 1 , 2 , and 3) on the Souris River were discontinued and site 4 was established in October 1934, all published daily discharge records for the early streamgages (sites 1,2 , and 3 ) were moved to streamgage 05117500 (site 4). All daily discharges for 1903 to current (2016) are available under streamgage 05117500 (site 4) in the USGS NWIS database (http://waterdata.usgs.gov/nd/ nwis/).

\section{Flood History of the Souris River at Minot}

The Souris River is prone to flooding in the spring months mainly because of a combination of winter snowpack melt and spring rainfall runoff. The wide, flat river valley and the low hydraulic slope of the region contribute to slow response times of the river system, causing prolonged flooding and ponded water in the basin. Severe thunderstorms or unusual amounts of rainfall during summer also can cause flash floods in the area.

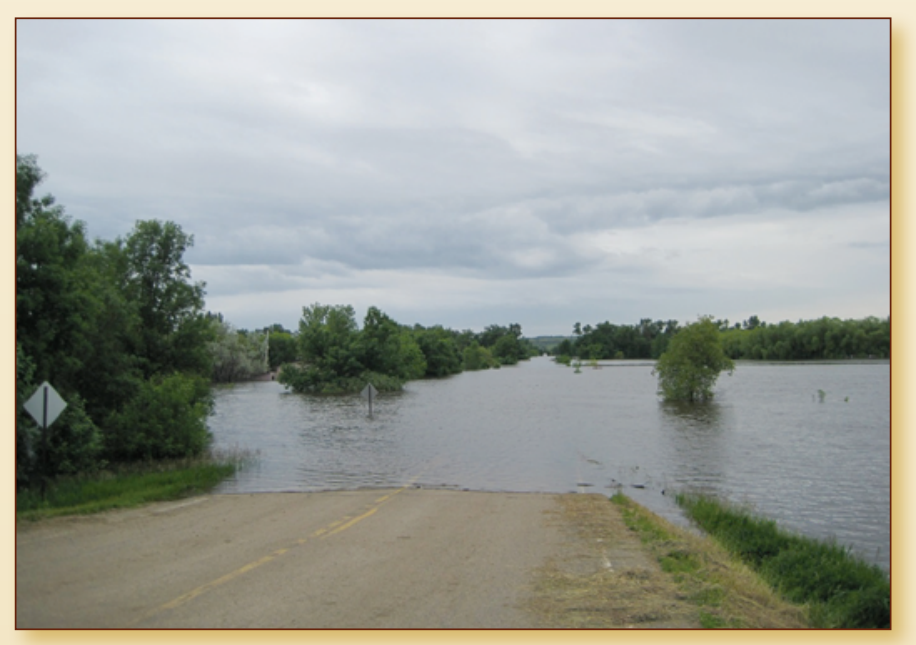

Figure 6. View on June 24, 2011, looking south of Souris River at streamgage 05117500 Souris River near Minot, North Dakota. (Photograph by U.S. Geological Survey). 
Several floods have been recorded in the Minot area during the years since streamflow records have been stored. Reports of flooding in Minot date back to 1881 or 1882 (depending on the source) with an observed gage height about 3 feet higher than the 1904 peak $(1,556.37$ feet above the North American Vertical Datum of 1988). The April 20, 1904, issue of the Minot Daily Optic quotes locals as describing a flood in 1881 with a gage height at least 3 feet higher than 1904. Weather data and observed streamflows from surrounding areas of North Dakota indicate that the flooding on the Souris River actually occurred in 1882 (G.E. Lyon, U.S. Army Corps of Engineers, written commun., 1964). No definitive records from the Minot area during 1881-82 are available. The annual peak streamflows for the Souris River above Minot, N. Dak., during 1904-2011 are shown in figure 7. The locations and datums of the streamgages on the Souris River have changed through time making gageheight comparisons difficult; however, the discharges are equivalent among all locations except for during extreme low-flow periods.

The two largest peak flows in the streamflow record for the Souris River in and near Minot occurred on April 20, $1904\left(12,000\right.$ cubic feet per second $\left.\left[\mathrm{ft}^{3} / \mathrm{s}\right]\right)$ and June 25, 2011 $\left(27,500 \mathrm{ft}^{3} / \mathrm{s}\right)$. The 2011 peak flow of $27,500 \mathrm{ft}^{3} / \mathrm{s}$ is from a measurement at the Broadway Bridge (site 5) and differs from the peak streamflow of $26,900 \mathrm{ft}^{3} / \mathrm{s}$ recorded at site 4 (fig. 7). The historic peak flood crests for the Souris River at Broadway Bridge at Minot, N. Dak., are listed in table 2.

Table 2. Historical crests for Souris River in Minot at Broadway Bridge at Minot, North Dakota.

[NAVD 88, National American Vertical Datum of 1988; USGS, U.S. Geological Survey; NWS, National Weather Service]

\begin{tabular}{|c|c|c|}
\hline $\begin{array}{c}\text { Flood crest } \\
\text { (feet above NAVD 88) }\end{array}$ & Date & Source \\
\hline $1,562.88$ & $6 / 25 / 2011$ & USGS, 2016 \\
\hline${ }^{1} 1,559.37$ & ${ }^{2} 1881$ & USGS 2016 \\
\hline $1,557.30$ & $4 / 18 / 1976$ & NWS 2016 \\
\hline $1,556.62$ & $4 / 20 / 1969$ & NWS 2016 \\
\hline $1,556.37$ & $4 / 20 / 1904$ & USGS 2016 \\
\hline
\end{tabular}

${ }^{1}$ Crest is an estimate based on reports from local resident.

${ }^{2}$ Review of weather records and additional historic flood information suggest that the 1881 peak may have actually occurred in 1882 .

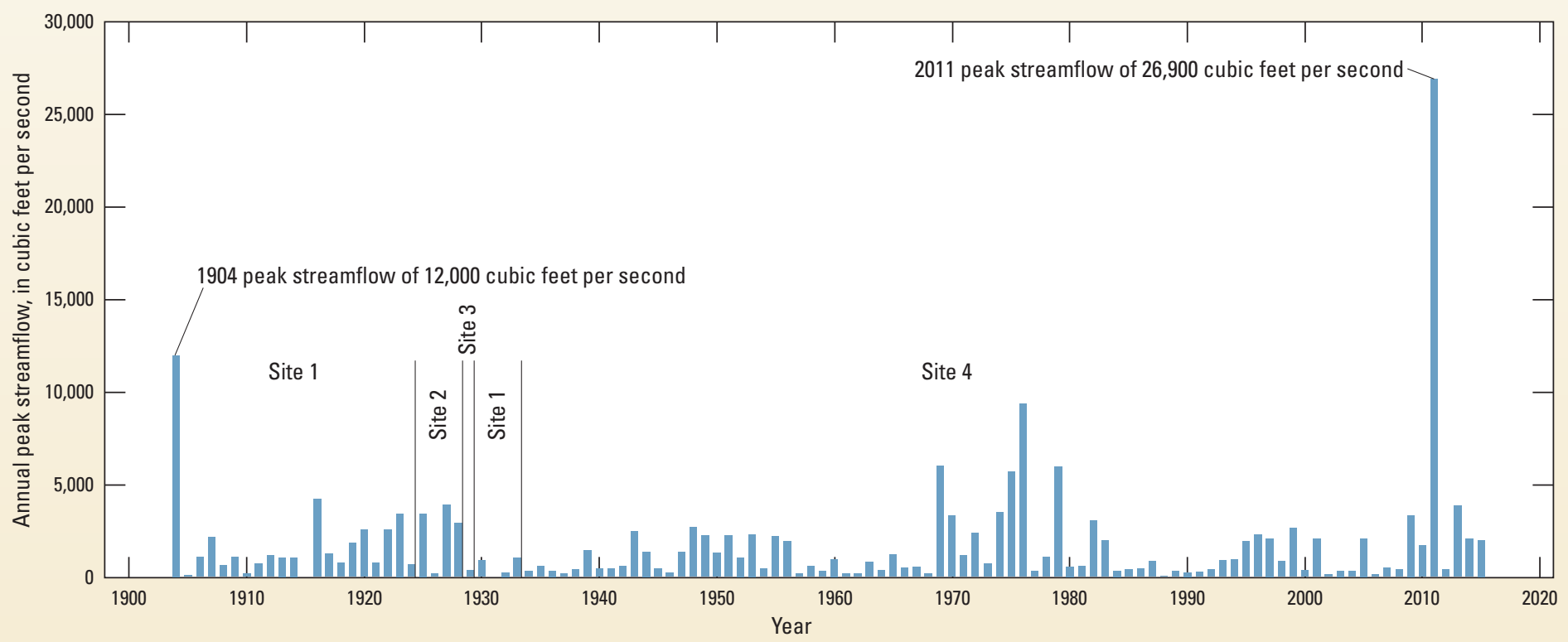

Figure 7. Annual peak streamflow for the period of record at streamgage 05117500, Souris River above Minot, North Dakota. (Data from U.S. Geological Survey, 2016; black vertical lines indicate four different streamgage locations.)

\section{References Cited}

Grover, N.C., 1936, Surface water supply of the United States, 1935, Part V, Hudson Bay and upper Mississippi River basin: U.S. Geological Survey Water Supply Paper 785, 283 p. [Also available at https:// pubs.er.usgs.gov/publication/wsp785.]

Hoyt, J.C., 1904, Report of progress of stream measurements for the calendar year 1903, Part IV, Interior Basin, Pacific, and Hudson Bay drainage: U.S. Geological Survey Water Supply and Irrigation Paper No. 100, 533 p. [Also available at https://pubs.er.usgs.gov/publication/wsp100.]

National Weather Service, 2016, Advanced Hydrologic Prediction Service, Souris River at Minot-Broadway Bridge: accessed June 8, 2016, at http://water.weather.gov/ahps2/hydrograph. php wfo $=$ bis \& gage $=$ mion 8 .
North Dakota State Water Commission, 1927-28, Thirteenth Biennial Report of the State Engineer to the Governor of North Dakota: accessed April 20, 2016, at http://www.swc.state.nd.us/info_edu/ reports_and_publications/biennial_reports/.

North Dakota State Water Commission, 1929-30, Fourteenth Biennial Report of the State Engineer to the Governor of North Dakota: accessed April 20,2016, at http://www.swc.state.nd.us/info_edu/ reports_and_publications/biennial_reports/.

Sauer, V.B., and Turnipseed, D.P., 2010, Stage measurement at gaging stations: U.S. Geological Survey Techniques and Methods book 3, chap. A7, 45 p. [Also available at http://pubs.usgs.gov/tm/tm3-a7/.]

U.S. Geological Survey, 2016, Peak streamflow for North DakotaUSGS 05117500 Souris River above Minot, ND: accessed June 8, 2016, at http://nwis.waterdata.usgs.gov/nd/nwis/peak/?site_ no $=05117500 \&$ agency_cd=USGS\&amp. 